\title{
Mr James Malloch, M.A.
}

He was first Executive Officer to the National Committee for the Training of 'Teachers, and died on 3rd April 1932, about a month before reaching his seventy-second birthday. Mr Malloch was a native of Perth. He graduated Master of Arts at the University of Edinburgh in 1886, distinguishing himself particularly in English Literature and Philosophy. After various teaching appointments in Edinburgh, Arbroath, and Hamilton, he joined the staff of Harris Academy, Dundee. With this city a large part of his life was most closely associated. After a period as Second Master at Harris Academy, Dundee, he was appointed Headmaster of Brown Street School, and later of Blackness School. His remarkable success as a Headmaster led to his appointment as Lecturer on Education to the students in University College, Dundee.

In 1907, when the Provincial Committees for the Training of Teachers were first established, he was clearly marked for higher office, and became Director of Studies to the St Andrews and Dundee Provincial Committee. With the Dundee centre Mr Malloch's name will always be closely associated. He established for it a great reputation, which he was zealous to sustain through many vicissitudes of fortune. The building which stands in Park Place, Dundee, to-day is a permanent memorial to his pertinacity and enterprise. Prior to the erection of this Training College Mr Malloch visited America, and there gained many hints in building construction which were used to great advantage in the Dundee College.

In 1920 the responsibility for the professional training of teachers in Scotland passed into the hands of a National Committee for the Training of Teachers, established by Minute of the Committee of Council on Education in Scotland, and Mr Malloch received the important appointment of Executive Officer to this new Committee, with headquarters in Edinburgh. Here he had a task which demanded all his powers of organisation and required tact and resourcefulness in the handling of a situation that contained vexatious elements. His supreme good sense enabled him, along with the late Professor Darroch as his Chairman, to solve on rational lines many difficult problems of an imperium in imperio.

He retired from this position in 1925 and went back to Dundee, where his practical interest in education continued to be manifested by his membership of the Dundee Education Authority. 
His death removes one who had the supreme gift of foresight. He could anticipate future developments and was never content merely to mark time. With his students he was at all times popular. He had a rare gift of friendship, and in every educational quarter in Scotland he will long be remembered as a man who brought to his daily task a high sense of purpose, great cheerfulness and force of character, to which were allied conspicuous ahilities in administration.

He was elected a Fellow of the Society in 1925.

J. R. P. 